\title{
Inspiration and the Texts of the Bible
}

\section{Dirk Büchner \\ Department of Biblical Literature \\ University of Durban-Westville}

\begin{abstract}
This article seeks to explore what the inspired text of the Old Testament was as it existed for the New Testament authors, particularly for the author of the book of Hebrews. A quick look at the facts makes. it clear that there was, at the time, more than one 'inspired' text, among these were the Septuagint and the Masoretic Text 'to name but two'. The latter eventually gained ascendancy which is why it forms the basis of our translated Old Testament today. Yet we have to ask: what do we make of that other text that was the inspired Bible to the early Church, especially to the writer of the book of Hebrews, who ignored the Masoretic text? This article will take a brief look at some suggestions for a doctrine of inspiration that keeps up with the facts of Scripture. Allied to this, the article is something of a bibliographical study of recent developments in textual research following the discovery of the Dead Sea scrolls.
\end{abstract}

\section{INTRODUCTION}

The use of the Old Testament in the New Testament is a very wide subject. In this essay I wish to limit my investigation of this topic to one level only: the textual level. Accordingly, I wish to pose a single question: what do we learn about the shape of the Old Testament text ${ }^{1}$ from the evidence of the New Testament? The answer to this question will lead us to some important considerations about text and inspiration of Scripture. The interesting discussion that arises from this, as an aside, is the contribution of scientific knowledge to belief and doctrine. Both, I believe, are dynamic and not static.

\section{THE TEXT OF THE OLD TESTAMENT IN THE NEW TESTAMENT 2}

What is so inviting about this topic is the fact that all over the New Testament, we find quotations of different versions of the Old Testament than the one we are familiar with. In our Bibles, the Old Testament follows a Hebrew text known as the Masoretic Text, or $\mathrm{MT}^{3}$. In the new Testament, we find Old Testament quotations which follow the 
MT, but also ones which have their origin in the Greek translation of the Old Testament, the so-called Septuagint, or LXX' ${ }^{4}$. Most often the New Testament will use the LXX's version of a verse where it differs from the MT, particularly when it suits the author's exegesis of that Old Testament passage. This is because the New Testament writers viewed the canonical Scriptures not as something stable, but rather as something fluid 5 . A fine case in point is the phrase 'ears you have dug for me' found in the Hebrew text of Psalm 40:6. It is quoted in the New Testament (Heb 10:5) as 'a body you have prepared for me' which is the rendition of that verse in the LXX. The author of Hebrews wanted to make a point about the incarnation, and there was a beautiful verse in a Psalms manuscript he could use!

Immediately the question arises: what do we make of this evidence? The New Testament writers, says Brevard Childs, bore witness to Christ by transforming the Old Testament in a way that stood in much tension with the original sense of the Hebrew Text $^{6}$. What he is saying is that the Septuagint is in many respects quite different from the Masoretic Text. And yet it was the Bible of the Early Church. It is only natural to ask: is it no longer the Bible of the Church? Had its role as shaper of the earliest Christian Theology run its course with the establishment of the Masoretic Text as accepted text in 200. A D? Was its subsequent role merely a witness to the accepted text that could be consulted at obscure passages, and from which conjectural emendations could be made, such as is the practice in the text-critical apparatus of Biblia Hebraica?

The growing reply to this is no. The Septuagint is currently being reinstated as a separate and equally important Old Testament text ${ }^{7}$. That is why references to it are cropping up more and more in the footnotes of modern Bible translations - notice this practice in the NIV for example. A new English translation of the LXX is under way as a companion volume to the NRSV, to which the present author is a contributor. In addition to this there is renewed interest today in the importance of the Septuagint as key witness to the most ancient text of the Old Testament. This is because of the fact that manuscripts which are similar to the LXX where it diverges from the Hebrew text have been found among the Dead Sea Scrolls, not in Greek but in Hebrew ${ }^{8}$. This evidence suggests that there existed another Hebrew text which was well known in the last two centuries B C. Consequently, we cannot dismiss all the differences of the LXX as mistranslation or paraphrase of the translator. (Cf. the use of 'virgin' in the LXX Isaiah 7:14 for the 'young woman' of the Hebrew MT. Matthew, of course, quotes the verse from the LXX. Which reading was originally intended by Isaiah? No-one knows the answer to that one). Many times we have to presuppose a different, and perhaps more original parent Hebrew text behind the divergent readings of the LXX ${ }^{9}$. To sum- 
marise, the LXX represented for the New Testament authors a different, but equally authoritative Old Testament. In their day, the practice of being selective when one had a variety of equally authoritative texts to choose from was not strange. We see this at Qumran. Different texts of the same book existed side by side for the community, and there seemed no need to eliminate one in favour of another ${ }^{10}$.

The book of Hebrews is a good example of how a NT author selects the interpretation of the Septuagint to suit his exegesis because he quotes from the LXX without regard for the MT ${ }^{11}$. Hebrews is therefore quite unique in the way it respects the Septuagint ${ }^{12}$. This is surprising considering that neither Paul nor the Gospel writers limit themselves to one single textual tradition ${ }^{13}$. Furthermore, the author of Hebrews follows the LXX in places where it differs from the Masoretic Text. We shall look at some of those instances in greater detail, below. Often he bases his entire exegesis upon such deviations, such as in 10:5-10 and 12:26.

Thus one might ask, is there a different Old Testament to the one we have in our Bibles? Or, what do we mean by canonical Bible text? Or, which is the inspired text - Septuagint or Masoretic Text? In arriving at an answer to these questions I hope to provide in this article some contribution to what we know of the mechanics of inspiration from the evidence provided by the various Bible texts, much like scientists are slowly unravelling the origins of the universe from evidence provided by the Hubble telescope. We know that God created the universe, but astronomy is coming up with suggestions as to how. We know that the Bible is inspired by God, but the science of textual recovery (textual criticism) is constantly making new suggestions as to how it came to us.

\section{CITATION FORMULAE IN HEBREWS}

In contrast with the rest of the New Testament, Hebrews uses the citation-formula 'God (or Christ or the Holy Spirit) says'. The formulae 'it is written' or 'the Scripture says' commonly found elsewhere in the New Testament do not occur in Hebrews. Curiously, even where God in Old Testament passages is mentioned in the third person, He becomes the first person speaker in Hebrews $(1: 6,9 ; 4: 4,7 ; 7: 21$ and 10:30). Furthermore, Old Testament passages are introduced as if Christ himself spoke them $(2: 12 \mathrm{ff}$. and $10: 5-7)^{14}$. 


\section{DETAILED EXAMPLES WITH CLARIFICATION WHERE THE AUTHOR FOLLOWS THAT TEXT WHICH DEVIATES FROM OUR MASORETIC TEXT}

It is only fitting that by textual comparison we try to see what was behind these instances of exegesis. Goppelt does well to caution that we are ignorant of two things in this regard. One, we do not know to what extent MT is original. Two, we do not know to what extent the author is quoting from memory ${ }^{15}$. To this Michel would reply that the LXX-quotations are verbatim to such an extent that there is no doubt that the author cites a written text ${ }^{16}$. McCullough agrees. The long and accurate quotations from Jeremiah and Psalms suggest that he did not quote from memory but used a written source ${ }^{17}$.

Explanation of abbreviations used below:

$$
\begin{array}{ll}
\text { SP } & =\text { Samaritan Pentateuch (Hebrew) } \\
\text { GNT } & =\text { Greek New Testament } \\
\text { TO } & =\text { Targum Onqelos (Aramaic) } \\
\text { DSS } & =\text { Dead Sea Scrolls or Qumran Texts }
\end{array}
$$

\subsection{Case 1 Hebrews 1:6}

* GNT: 'and let all the angels of God worship him'

* $\quad \mathrm{MT}$ = SP (Deut 32:43): 'sing joyously, o nations, of his people'21, 'Rejoice, O nations, with his people (NIV)'.

* LXX and DSS (very expansionistic here): 'let the heavens rejoice with his people: and let all the angels (alternative tr "sons of God") worship him' (cf the Jerusalem Bible)

* Targum Onqelos: 'sing to his people, $O$ nations'

* Ps 97:7 LXX is virtually identical to the reading in Hebrews.

Conclusion: Here we see the author of Hebrews selecting from a textual tradition represented by LXX and Qumran, which is quite different from the Masoretic tradition supported by SP and TO. 


\subsection{Case 2 Hebrews 10:37-38}

* GNT: 'for yet a very little while, he who comes shall come and not tarry. But my ${ }^{22}$ righteous one shall live by faith and if he draws back my soul will not delight in him' (some NT manuscripts read "by my faith" which is the LXX rendition).

* MT (Hab 2:3-4) 'For the vision is yet for the appointed time. And it hastes towards the end and shall not lie: though it tarry, wait for it because it will surely come, it will not delay. Behold: his soul is puffed up, it is not upright in him; but the righteous shall live by his faith'

* LXX: 'Because the vision is yet for an appointed time, and it will appear at length and not in vain: if he is late, wait for him; because he will surely come, he will not delay. If he draws back, my soul has no pleasure in him, but the (my) righteous will live by (my) faith'

Conclusion: Detailed comment on this verse may be found in Bruce ( $p$ 273) and Michel (p 362). Here I have only indicated the differences in the LXX and MT. The MT concentrates on the vision, but the LXX talks of the one who is coming. This suits the New Testament exegesis perfectly and that is why it was preferred.

\subsection{Case 3 Hebrews 12:6}

* GNT: 'because the Lord corrects everyone he loves and punishes every son whom he receives'

* MT (Prov 3:12): 'because the Lord corrects those he loves, as a father [corrects] ${ }^{23}$ a son of whom he is proud'

* LXX: 'because the Lord corrects everyone he loves and punishes every son whom he receives'

The point here is that the missing verb in the second half of the verse in MT may be adduced from the LXX reading, which, says Bruce, probably reflects the original sense $^{24}$. The LXX's 'receive' for MT's 'to be proud' is not to be considered a variant 25 . 


\subsection{Case 4 Hebrews 10:5}

* GNT: "Therefore when he came into the world, he said, "sacrifice and offering you did not desire, but a body you have prepared for me"

* MT: 'Sacrifice and offering you did not desire, ears you have dug out for me'

* LXX: 'Sacrifice and offering you did not desire, but a body ${ }^{26}$ you have prepared for me'

Conclusion: here once again the author of Hebrews chooses the reading that best supports his exegetical argument. He is talking about Christ's incamation, and 'body' fits better than 'ears'.

A fine summary of the author's attitude to his text may be found in Mc Cullough's article. He makes three points:

* The author considered the Old Testament as a divine oracle relevant to the readers of his day, which had to be interpreted and made understandable to them. To this end he was quite ready to make alterations to the text to avoid ambiguity and for the sake of emphasis.

* He nevertheless shows a reverent and cautious attitude to his text which contrasts with that of his contemporaries.

* He used the text that was known to his local congregation and chose it deliberately to avoid confusion, and even opposition ${ }^{27}$.

\section{THE SEPTUAGINT, THE OLD TESTAMENT CANON AND THE TEX- TUAL HISTORY OF THE OLD TESTAMENT}

Sanders puts it well when he says that in both fields of text and canon of the Old Testament, we are on an exciting new track. Whereas the practice of textual recovery used to be viewed as a preliminary activity in exegesis, and the study of canon a final stage of literary criticism, the two now need to be viewed as interrelated ${ }^{28}$. Consider our present topic. What was considered the Old Testament canon for the early Church and the New Testament writers? It was a variegated soup consisting of the Masoretic Text tradition, the Septuagint and many other renditions of the Old Testament, including readings which stem from the Samaritan Version of the Pentateuch. This makes the text-critic prick up his ears and say, well, why do they quote from the LXX rather than 
from the Accepted Hebrew text? Can this tell us something about the importance of the LXX, or is it merely a paraphrase? Let's see if we cannot find similarities in the Hebrew texts from the Dead Sea to corroborate the Greek. Does the LXX have a Christian bias or is it a Jewish text? And so on.

Because of the discovery of much textual data from the period between the Testaments, including the so-called Dead Sea Scrolls, the very foundational concept to textual criticism, the history of how the Old Testament text came to be, has recently had to be rewritten. What scholars have found is that the nature of canonical literature lies as much in its adaptibility as in its stability 29.

\section{THE STATE OF THE QUESTION? THE VARIETY OF THE OLD TESTA- MENT TEXTS AND OUR UNDERSTANDING OF INSPIRATION.}

An extreme view held by 17 th century protestant orthodoxy is illustrated by the following summary of some of the principles set out by Johann Heinrich Heidegger of Zürich, the redactor of the Formula Consensus Helvetica (1675):

* The Word of God given through Moses, the Prophets and the Apostles has been preserved for the Church, free of all corruption.

* The Hebrew text of the Old Testament is inspired both in its vowels and consonants: the vowel points, or at least the meanings signified by them, have therefore been inspired.

* The Hebrew reading, thus safeguarded, cannot be emended by appeal to the LXX, the Samaritan Pentateuch, the Targums, or conjecture.

In mitigation it must be said that the Swiss church did not accept these principles ${ }^{30}$ ! How precisely do we view the work of the inspired writer? Much has been written about this and much has been debated. Minimalists reject the notion of inspiration entirely, while extreme fundamentalists hold on to something similar to Heidegger's notion just mentioned. Vawter's treatment of Inspiration from both a Catholic and Protestant point of view is extremely thorough and yet reads easily. He puts it succinctly when summing up the current state of affairs: Traditionally the process of composition was based on a concept of authorship 'somewhat at variance with what we now know to have been responsible for at least a major portion of the Bible'31. To many scholars, therefore, it has seemed that a much more radical adjustment of thinking is neces- 
sary if there is to be a notion of inspiration that truly corresponds to all the Biblical realities ${ }^{32}$. Beegle agrees with this: 'a truly Biblical formulation of inspiration must give equal weight to the teaching and to the facts of Scripture'. By facts he means firstly the correlation between historical details in the Bible and extra-Biblical data and the use of the Old Testament in the New Testament ${ }^{33}$.

He treats a good number of examples including the allusions in Jude to non-canonical literature, (which must also have been done under inspiration!). This book is well worth reading by anyone interested in the nitty-gritty of arguments regarding infallibility and inspiration. However, he did not take the issue of the Old Testament quotations in the New Testament any further than to conclude that there is no reason not to regard both MT and LXX as inspired.

Abraham's critical treatment of inspiration from a modern standpoint is a fine book to get hold of. He does not give much attention to the textual data, but argues more theologically. We need, he says, to be sensitive to the rich diversity of the Jewish past. In particular we need to distinguish sharply between seeing the Bible as normative and seeing the Bible as verbally inspired ${ }^{34}$. He goes on to show that there is no evidence from the way the New Testament authors cite the Old Testament that they regarded it as inerrant and verbally inspired in its original autographs $\mathrm{s}^{35}$.

One writer, who wrote from the fundamentlist point of view an essay called 'Inerrancy and Textual Criticism' 36 dealt mostly with the problem of differences between ancient Old Testament manuscripts that arose out of copying errors and the inadequate duplicating process the Bible has been subject to for the last 2500 years before the advent of Xerox. For him the way out of his dilemma of seeing textual differences on every page of his critical edition, is to speak of the 'inerrancy of the Bible in terms of "the original autographs" or "as originally given" so that the Bible is said to be inerrant or entirely trustworthy not in the copies or translations, but in the original writing'37. The substantial differences between MT and the LXX as found in the NT is ignored in this piece of work.

In addressing the notion of 'original autographs' which became corrupt or were copied incorrectly, a few observations are necessary. We now know that differences between the major texts of the Old Testament are attributable to more than copying errors; rather, there existed a very loose state of affairs as to what was the accepted text of the Old Testament before the standardisation of the Hebrew text at the beginning of the 3rd century AD. Sanders puts it this way: 'Whether there were three basic local families of texts or there were numerous types of texts, it became quite clear that up to and including most of the Herodian period the text of the Hebrew-Aramaic Bible was relatively fluid'38. This state of affairs was happily exploited by the Inspirator of the 
New Testament authors, whichever way we want to look at it, and we have to reconcile this with whatever we wish to believe about inerrancy and inspiration ${ }^{39}$. Therefore it is somewhat reductionistic to say that we believe in the inerrancy and inspiration of the one 'original' text from which all texts developed, because that view turns the pyramid of scientific evidence onto its head. In fact, we are more certain now that the way in which the Old Testament text came to us was a process from many texts to few texts rather than from one original to many copies and translations: down the tree rather than up the tree! After the time of the writing of the book of Hebrews there was a completion of the process of stabilisation that had already started taking place and had its beginnings in the last centuries before Christ. The Masoretic Text became the accepted text for Judaism, and from that time, when a scribe got hold of any manuscript, he tended to correct it according to the accepted text. The Septuagint also underwent such revision ${ }^{40}$, but that's another story.

\section{SO WHAT?}

Now once you and $I$ know that there is more than one 'inspired text' where do we go from here? A good place to start would be to read the preface of the next Bible version we pick up to see what its attitude is towards the original texts. Responsible Bible translations are those that admit ignorance of what is meant by 'the best text'. The preface to the REB is a lot less pretentious than that of the NIV, and in it they say:

The text is not infrequently uncertain and its meaning obscure, and after all the study of the texts and versions, the languages and cultures of the ancient Near East, there remain a number of passages where the translator must either leave a blank in his version or, as the NEB translators and the present revisers have chosen to do, resort to conjectural emendation of the Hebrew text ${ }^{41}$.

Am I saying that we need to undo the process of stabilisation of the canonical text? Perhaps so, but also to be aware of and appreciate the multifarious 'text' that served as Scripture for Jesus and the New Testament authors. Childs gives us a few helpful pointers here 42 :

* The Church has always been in some measure uncertain of the form of the Christian Bible 43 . 
* We need to find a theological solution to this that is not biblicist in its approach. This means that every practice of the early church cannot simply be copied by successive generations of Christians.

* In real terms, just because the New Testament authors employed Hellenistic techniques of exegesis such as allegory, or used a Greek Old Testament, it does not mean that we have to follow suit.

* Underlying this argument, says Childs, is an appeal for a kerygmatic, that is, christological reading of Scripture rather than a biblicist one.

* The Church is not in deep confusion because of uncertainty over its precise text. There was no great change in the function of the Church when the apocrypha were included in the Geneva Bible, nor when they were excluded in the KJV!

* The basic theological issue can best be formulated as the church's ongoing search for the Christian Bible. The hearing of God's Word is repeatedly confirmed by the Holy Spirit. At the same time, the Church confesses its inadequacy of reception, 'while rejoicing over the sheer wonder of the divine accomodation to limited human capacity'44.

If I may add one further point, Bible translations do become dated and need to be updated by new finds in Biblical research.

\section{WHAT DOES THIS MEAN FOR ME IN THE PULPIT?}

8.1 Let us teach our people about the doctrine of inspiration! But let us open to them a window into how to understand inspiration, that it was never a verbal, mechanical process, as some would wish it was, but one which was very human and about which we have a lot more to discover in order to understand.

8.2 Let us also teach our people that there are unanswered questions about the Bible, which may come to light only in another generation. Such a confession appeals to me more than to be able to say unequivocally that the Bible is a forthright, incontestible and unambiguous Book of Faith. I believe that to admit this is part of the Christian Way of weakness (not to mention honesty!) rather than bigotry. Also it means that for us a normal kind of godliness and devotion is required, nothing more, to become full recipients of God's revelation. We do not need superteachers or a super-spirituality to see God and to hear Him. A view of inspiration 
that adds to it a magical flair, instills a wrong kind of awe for the Scriptures, as if it would then be a magic book, whose key lies in the hands of a few enlightened persons.

8.3 I have indicated that the Septuagint was regarded as authoritative and inspired for the very first Christians. It is always a good thing to have and use alternative versions, so what better one is there to have than the very oldest? When our NRSV Septuagint translation appears, buy one!

\section{End Notes}

1 For anyone remotely interested in knowing how the Old Testament text came to us, Ralph Klein's Textual Criticism of the Old Testament: The Septuagint after Qumran, Old Testament Series (Philadelphia: Fortress Press, 3rd ed 1981) is compulsory reading.

2 Although it is by now quite dated, M P Miller's 'Targum, Midrash and the Use of the Old Testament in the New Testament', Journal for the Study of Judaism 2 (1971):29-82 provides an excellent account of the work done on each section of the New Testament as well as an exhaustive bibliography.

3 The text printed in Biblia Hebraica, one of the most popular editions of the Hebrew Bible, is merely an unchanged reproduction of a manuscript from the eleventh century A D (Klein, op. cit., vii). Sister texts of the Masoretic tradition are the Isaiah text from Qumran, and the texts discovered at Nahal Hever, close by.

4 The Septuagint is a translation made in Egypt for Greek-speaking Jews, and dates back to the third century BC. Thus it is the oldest textual witness to the Old Testament, that is, it was the very first translation ever made of the 'original' text. It is not a unified document, and varies in style from very close to the Hebrew to vastly different, depending on the book in translation. For a synopsis of the complicated history of the LXX, see Klein, op. cit., 1-10. The discovery of the Dead Sea Scrolls has revolutionised our ideas about the origin of the Old Testament text and increased our awareness of the importance of the Septuagint. A very good synopsis of the current state of affairs in Old Testament textual scholarship may be found in $\mathrm{J}$ E Sanderson, An Exodus Scroll from Qumran (Atlanta: Scholars Press, 1986)

5 J A Sanders, From Sacred Story to Sacred Text (Philadelphia: Fortress Press, 1987), p $133 \mathrm{ff}$.

6 B S Childs, Biblical Theology of the Old and New Testaments (London: SCM, 1992), p 65.

7 J Lust, 'Translation Greek and the Lexicography of the Septuagint', Journal for the Study of the Old Testament 59 (1993):109-120, p 114, with bibliography. 
8 Because none of the early manuscripts of the Masoretic text exist anymore, scholars have sought to recover some of those earlier manuscripts by retranslating the LXX, because of its great age, back into Hebrew. This has been done, for example, by Wellhausen and Driver in the case of I Samuel $1 \& 2$, whose Greek text is shorter and more concise, and whose Hebrew text they were convinced was corrupted by scribal errors. And lo and behold, a Hebrew text appeared at Qumran which, had the two gentlemen still been alive, would have confirmed their suggestions, because it contained a shorter, less repetitive version which was the exact equivalent of the Greek. The same applies to the LXX version of Jeremiah which is shorter by 1/7 than its Hebrew counterpart. At Qumran they found a shorter Hebrew text which is a type of text that LXX Jeremiah might have been translated from.

9 This is not always the case, as I have shown in a recent article on the LXX text of Exodus. Sometimes, exegetical variants appear in the text which mirror the exegesis of the Rabbinic commentary to Exodus, the Mekilta deRabbi Ishmael. Other times, there is definite evidence of a different parent text (D L Buchner, 'Exegetical Variants in the Septuagint, an Evaluation', Journal of Northwest Semitic Languages 22/1 (1996), 35-58.

10 E Tov, 'Some Reflections on the Hebrew Texts from which the Septuagint was Translated', Journal of Northwest Semitic Languages 19 (1993):107-122, p 113.

$11 \mathrm{~J} \mathrm{C} \mathrm{McCullough,} \mathrm{'The} \mathrm{Old} \mathrm{Testament} \mathrm{Quotations} \mathrm{in} \mathrm{Hebrews',} \mathrm{New} \mathrm{Testament} \mathrm{Studies} 26$ (1980):363-379, p 377.

12 Sanders, op. cit. 140.

13 Cf. C D Stanley, Paul and the Language of Scripture Society for New Testament Studies Monograph Series 74 (Cambridge, MA: Cambridge University Press, 1992) and D-A Koch, Die Schrift als Zeuge des Evangeliums (Tübingen: JCB Mohr, 1986).

14 L Goppelt, Theologie des Neuen Testaments, 2. Vielfalt und Einheit des apostolischen Christuszeugnisses (Göttingen: Vandenhoeck \& Ruprecht, 1976), p 576.

15 Loc.cit.

16 O Michel, Der Brief an die Hebräer. Meyers Kommentar XII (Göttingen: Vandenhoeck \& Ruprecht, 1975), p 151.

17 McCullough, op. cit., 368.

18 This Hebrew Version is a great favourite with the New Testament authors. In 1900 cases the LXX agrees with SP against MT (Tov, op. cit., 112).

19 A Sperber, (ed). The Bible in Aramaic 4 vols (Leiden: E J Brill, 1992). 
20 All of the Qumran documents are available for scrutiny today, whether on microfiche, or in the now rapidiy appearing editions of Discoveries in the Judaean Desert (Oxford: Clarendon Press), which are available in most South African Libraries.

21 S R Driver, Deuteronomy in The International Critical Commentary (Edinburgh: T \& T Clark, 3rd ed, 1973), p 380.

22 This word has been transposed from after 'faith' (as in the LXX B text) to this position. Under the influence of Romans 1:17, the 'my' is omitted from the later New Testament manuscripts (F F Bruce, The Epistle to the Hebrews [Michigan: Eerdmans, 1985], p 266.)

23 The LXX has 'mastigoi' meaning 'punishes'. The Hebrew has no verb there, but the vowels to ke-av 'like a father' may be changed to yach-iv 'punishes'.

24 Bruce, op. cit., 357.

25 Michel, op. cit., 441.

26 There is a LXX reading that has 'otia', (ears), and this is followed by Rahlfs' text, but the best mss have the reading 'soma', (body) (Michel, op. cit., 337).

27 McCullough, op. cit., 379.

28 Sanders, op. cit., 22.

29 Sanders, op. cit., 133.

30 B Vawter, Biblical Inspiration. (London: Hutchinson, 1972), p 82.

31 There is a painting depicting the four gospel writers writers sitting in four cubicles of a common room, simultaneously writing their gospels.

32 Vawter, op. cit., 104.

33 D M Beegle, The Inspiration of Scripture (Philadelphia: Westminster Press, 1963), p 18.

34 W J Abraham, The Divine Inspiration of Holy Scripture (Oxford: Oxford University Press, 1981), p 97.

35 Op. cit., 105.

36 D Stuart, 'Inerrancy and Textual Criticism' in Inerrancy and Common Sense, ed J R Michaels and R R Nicole (Grand Rapids: Baker, 1980). 
37 Stuart, op. cit., 101.

38 Sanders, op. cit., 128.

39 I deliberately mention these two concepts in one breath, even though they ought not to be associated. See Vawter, op. cit., 132 on the pitfalls of making inerrancy a corollary of inspiration. Hence it is a pity that in the NIV preface we find the word 'infallible' which would endear it to a fundamentalist readership, not to mention a fundamentalist clientele! See R P Carroll, 'As Seeing the Invisible: Ideologies in Bible Translation', Journal of Northwest Semitic Languages 19 (1993), 79-94 (esp p 85-86): 'After reading the preface to the NIV, my impression of the translators' first concern was not that of 'accuracy' or 'fidelity', but of a commitment to ideological purity of a fundamentalistic nature'.

40 One such reviser, Aquila, made such a literal translation of MT into Greek, that it became almost nonsensical in places. The first words of Genesis read thus: 'In the headpiece, God created with the heavens and with the earth', for the 'breshit bara elohim et ha-shamayim ve-et haarets'.

41 P. xvif.

42 Op. cit., $66 f$.

43 For example, the Geneva Bible retained the Apocrypha, while the KJV excluded them. Today there are version who do and versions who don't.

44 Childs, op. cit., 67. 